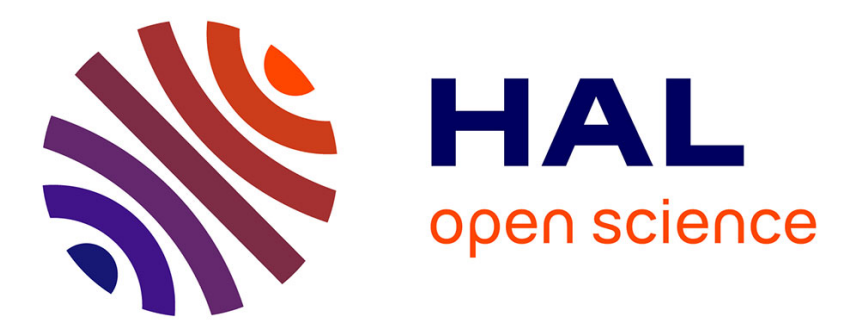

\title{
Chlamydial infections in duck farms associated with human cases of psittacosis in France
}

Karine Laroucau, Bertille de Barbeyrac, Fabien Vorimore, Maïthé Clerc, Claire Bertin, Taher Harkinezhad, Kristel Verminnen, Françoise Obeniche, Isabelle Capek, Christiane Bébéar, et al.

\section{To cite this version:}

Karine Laroucau, Bertille de Barbeyrac, Fabien Vorimore, Maïthé Clerc, Claire Bertin, et al.. Chlamydial infections in duck farms associated with human cases of psittacosis in France. Veterinary Microbiology, 2009, 135 (1-2), pp.82. 10.1016/j.vetmic.2008.09.048 . hal-00532499

\section{HAL Id: hal-00532499 \\ https://hal.science/hal-00532499}

Submitted on 4 Nov 2010

HAL is a multi-disciplinary open access archive for the deposit and dissemination of scientific research documents, whether they are published or not. The documents may come from teaching and research institutions in France or abroad, or from public or private research centers.
L'archive ouverte pluridisciplinaire HAL, est destinée au dépôt et à la diffusion de documents scientifiques de niveau recherche, publiés ou non, émanant des établissements d'enseignement et de recherche français ou étrangers, des laboratoires publics ou privés. 


\section{Accepted Manuscript}

Title: Chlamydial infections in duck farms associated with human cases of psittacosis in France

Authors: Karine Laroucau, Bertille de Barbeyrac, Fabien Vorimore, Maïthé Clerc, Claire Bertin, Taher Harkinezhad, Kristel Verminnen, Françoise Obeniche, Isabelle Capek,

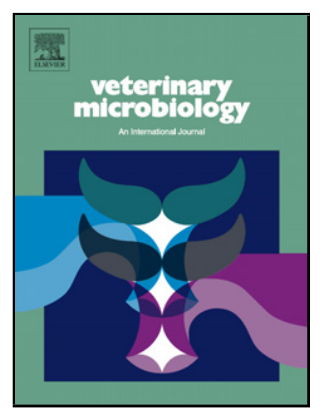
Christiane Bébéar, Benoit Durand, Gina Zanella, Daisy Vanrompay, Bruno Garin-Bastuji, Konrad Sachse

PII: $\quad$ S0378-1135(08)00393-3

DOI: $\quad$ doi:10.1016/j.vetmic.2008.09.048

Reference: $\quad$ VETMIC 4178

To appear in: $\quad$ VETMIC

Please cite this article as: Laroucau, K., de Barbeyrac, B., Vorimore, F., Clerc, M., Bertin, C., Harkinezhad, T., Verminnen, K., Obeniche, F., Capek, I., Bébéar, C., Durand, B., Zanella, G., Vanrompay, D., Garin-Bastuji, B., Sachse, K., Chlamydial infections in duck farms associated with human cases of psittacosis in France, Veterinary Microbiology (2008), doi:10.1016/j.vetmic.2008.09.048

This is a PDF file of an unedited manuscript that has been accepted for publication. As a service to our customers we are providing this early version of the manuscript. The manuscript will undergo copyediting, typesetting, and review of the resulting proof before it is published in its final form. Please note that during the production process errors may be discovered which could affect the content, and all legal disclaimers that apply to the journal pertain. 


\section{Chlamydial infections in duck farms associated with human cases of psittacosis \\ 2 in France}

4 Karine Laroucau $^{(1)^{\star}}$, Bertille de Barbeyrac ${ }^{(2)}$, Fabien Vorimore ${ }^{(1)}$, Maïthé Clerc $^{(2)}$, Claire Bertin ${ }^{(1)}$, Taher

5 Harkinezhad $^{(3)}$, Kristel Verminnen ${ }^{(3)}$, Françoise Obeniche ${ }^{(2)}$, Isabelle Capek ${ }^{(4)}$, Christiane Bébéar ${ }^{(2)}$,

6 Benoit Durand ${ }^{(5)}$, Gina Zanella ${ }^{(5)}$, Daisy Vanrompay ${ }^{(3)}$, Bruno Garin-Bastuji ${ }^{(1)}$, Konrad Sachse ${ }^{(6)}$.

7

$8{ }^{(1)}$ Bacterial Zoonoses Unit, French Food Safety Agency (AFSSA), Maisons-Alfort, France

$9 \quad{ }^{(2)}$ National Reference Centre for Chlamydiae, Centre Hospitalier Universitaire, Bordeaux, France

$10{ }^{(3)}$ University of Ghent, Department of Molecular Biotechnology, 9000 Ghent, Belgium

$11 \quad{ }^{(4)}$ Institut de Veille Sanitaire, Saint-Maurice, France

$12{ }^{(5)}$ Epidemiology, French Food Safety Agency (AFSSA), Maisons-Alfort, France

$13{ }^{(6)}$ Institute of Molecular Pathogenesis, Friedrich-Loeffler-Institut (Federal Research Institute for Animal 14 Health), Jena, Germany

15

16

17

18 "Corresponding author. Phone: (33) 1497713 00, Fax: (33) 1497713 44, E-mail address:

19 k.laroucau@afssa.fr 


\section{Abstract}

22 Five severe cases of psittacosis in individuals associated with duck farms were notified in France between January and March 2006. Diagnostic examination included serology and/or molecular

24 detection by PCR from respiratory samples. As a consequence, we investigated all duck flocks $(n=11)$ that were housed in the three farms where human infections occurred. While serology by complement fixation test was negative for all samples, cloacal and/or tracheal chlamydial excretion was detected by PCR in all three units. Notably, one duck flock was tested strongly positive in 2 of the 3 affected farms, and Chlamydophila (C.) psittaci strains were isolated from cloacal and/or tracheal swab samples from both farms.

30 Human samples and duck isolates exhibited the same PCR-RFLP restriction pattern, which appeared

31 to be an intermediate between genotypes $A$ and B. Analysis of ompA gene sequences and 32 comparison to those of the type strains showed that the isolates could not be strictly assigned to any 33 of the generally accepted genotypes of $C$. psittaci. Further analysis by MLVA of the PCR-positive 34 human samples revealed two distinct patterns, which were related to previously isolated C. psittaci duck strains.

Keywords: Chlamydophila psittaci, psittacosis, duck, genotyping, human infection

\section{List of abbreviations}

MLVA : Multiple Locus VNTR Analysis

MOMP: Major Outer Membrane Protein

VNTR: Variable Number of Tandem Repeats 


\section{Introduction}

Avian chlamydiosis is a well-recognised zoonotic disease caused by the obligate intracellular bacterium Chlamydophila (C.) psittaci, which occurs worldwide.

It was reported that more than 467 avian species could be affected by chlamydial infection (Kaleta and Taday, 2003). The infection is usually systemic and occasionally fatal in birds. The clinical signs vary greatly in severity and depend on the species and age of the bird, as well as the causative strain involved (Andersen, 1997). Avian strains of C. psittaci cover at least 6 serotypes (A to F) as determined by serovar-specific monoclonal antibodies (Andersen, 1991; 1997, Vanrompay et al., 1993). Each of these serotypes was assumed to be associated with a particular category of host species, i.e. type $A$ and $F$ with psittacines, type $B$ with pigeons, type $C$ with ducks, type $D$ with turkeys, and type $\mathrm{E}$ with pigeons and ratites. More recently, molecular typing methods have been developed, such as restriction fragment length polymorphism of PCR products (PCR-RFLP), which identified genotypes that are adequately reflecting the serotypes (Sayada et al., 1995, Sudler et al., 2004).

As far as the transmission of $C$. psittaci strains from birds to humans is concerned, certain professions like veterinarians, bird breeders, handlers and traders have been reported to face a particular risk (Huminer et al., 1988, 1992, Hinton et al., 1993, Saito et al., 2005). Typical transmission pathways involve inhalation of infectious aerosols during handling of infected animals, carcasses or tissues. Besides, contaminated faeces and feathers may play an essential role in zoonotic transmission. The symptoms of human psittacosis are variable, ranging from severe systemic disease to the complete absence of clinical signs (Andersen and Vanrompay, 2000).

C. psittaci infection in ducks has been reported previously in Europe, Australia and the USA (Chalmers et al., 1985, Arzey et al., 1990, Hinton et al., 1993, Léon et al., 2004, Guérin et al., 2006). Most of the recent human cases seemed to be linked to domestic poultry rather than psittacines (Heddema et al., 2006; Gaede et al. 2008).

In France, five cases of severe pneumonia were observed in February and March 2006. As the infected individuals were in close contact with farmed birds, avian influenza had been initially suspected, but was not confirmed by diagnostic findings. Subsequently, samples from patients and animals present at the three farms affected were examined for chlamydial infection. 
In the present paper, diagnostic data from real-time PCR, serology and genotyping by PCR-RFLP and multi-locus VNTR analysis (MLVA) are reported to characterise human and animal cases, and the prevailing epidemiological situation is described.

\section{Materials and methods}

\subsection{Humans}

\subsubsection{Samples}

Respiratory samples (throat swabs, tracheal aspirates or bronchoalveolar fluid) from four patients were collected during their hospitalisation, stored at $-80^{\circ} \mathrm{C}$ and sent to the National Reference Centre (NRC, Bordeaux, France) for chlamydiae in dry ice. Aliquots of early serum from each patient and late serum from two patients were also sent to the NRC (for dates of sampling see Table 1).

\subsubsection{Direct detection of $C$. psittaci from human samples}

Respiratory samples were analysed for C. psittaci using a specific incA real-time PCR protocol (Ménard et al., 2006) and by cell culture in order to obtain isolates. For PCR, clinical samples were extracted by using the automated MagNA Pure DNA extraction (Roche Diagnostics, Meylan, France) (De Martino et al., 2006). The TaqMan real-time PCR was carried out in a final volume of $25 \mu \mathrm{l}$ containing $5 \mu \mathrm{l}$ of extracted DNA using an ABI Prism7000 thermocycler (Applied Biosystems, Courtaboeuf, France).

Cell culture was performed on McCoy cells in minimal essential medium supplemented with $1 \mathrm{mM}$ glutamine, cycloheximide, glucose and $5 \%$ foetal bovine serum in a biosafety level 3 laboratory. Monolayers were made on $15 \mathrm{~mm}$ round coverslip in 1-dram shell vials and inoculated with $500 \mu \mathrm{l}$ of sample. After $48 \mathrm{~h}$ incubation, the monolayers were fixed and stained with monoclonal antibodies recognising genus-specific chlamydial LPS (ImagenTM Chlamydia, Dako, I2L Elitech, Labarthe Inard, France).

\subsubsection{Serology}

A commercialised immunofluorescence test was used (Chlamydia MIF, Focus, Eurobio, France). This assay can measure responses to IgM and IgG subclasses. Each well contains four spots, one yolk sac 
control, and three individual antigen spots consisting of elementary bodies of C.psittaci, C. trachomatis and C. pneumoniae suspended in a yolk sac matrix. Each run included a positive

104 (murine serum) and negative control (human serum). The reciprocal of the highest serum dilution giving apple-green fluorescence was termed the serum endpoint titre for IgG. For IgM, one dilution was tested (1/16), and the result was assessed qualitatively, i.e. positive or negative.

2.2. Ducks

\subsubsection{Samples}

110 Samples were collected from duck flocks present in the 3 farms (A, B and C) affected by human cases. While all duck flocks present in plants A $(06-0859,06-0870,06-0871)$ and B $(06-0885,06-0886$ and 06-0889) were sampled, due to the large size of farm C (60 000 ducks in 15 farm premises), only the 5 flocks related to the two human cases were included in the sampling $(06-1018,06-1019,06-$

114 1020, 06-1021 and 06-1022). In each sampled flock, 20 animals were examined. Ducks were submitted to bleeding, and cloacal and tracheal swabbing. One panel of swabs was stored in conservation buffer SPG (Spencer and Johnson, 1983) at $-80^{\circ} \mathrm{C}$ until inoculated into chicken eggs. The other panel was stored dry at $-80^{\circ} \mathrm{C}$ until subjected to DNA extraction. Age and bleed information of the animals examined are summarised in Table 2.

\subsubsection{Direct detection of chlamydiae from avian samples}

121 The dry panel of cloacal and tracheal swabs was subjected to DNA extraction using a QIAamp DNA

122 Mini Kit, following the buccal swab protocol (Qiagen, Courtaboeuf, France). DNA was eluted with $123150 \mu \mathrm{l}$ of $\mathrm{AE}$ buffer and stored at $-20^{\circ} \mathrm{C}$ before analysis.

124 A Chlamydiaceae-specific real-time PCR targeting the 23S rRNA gene was used in this study (Ehricht et al., 2006). The protocol includes primers Ch23S-F (5'-CTGAAACCAGTAGCTTATAAGCGGT-3'),

126 Ch23S-R (5'-ACCTCGCCGTTTAACTTAACTCC-3'), and probe Ch23S-p (FAM-5'127 CTCATCATGCAAAAGGCACGCCG-3'-TAMRA). Each reaction mix contained $2 \mu \mathrm{l}$ sample DNA 128 template, $10 \mu \mathrm{l}$ of Universal Mastermix 2X (Applied Biosystems), $0.5 \mu$ l of each primer $(25 \mu \mathrm{M})$ and $1292 \mu \mathrm{l}$ of the probe $(1 \mu \mathrm{M})$, and $5 \mu \mathrm{l}$ deionized water. The temperature-time profile was $95^{\circ} \mathrm{C} 10 \mathrm{~min}$, 13045 cycles of $95^{\circ} \mathrm{C} 15 \mathrm{~s}, 60^{\circ} \mathrm{C} 60 \mathrm{~s}$. 
2.2.3. Inoculation onto chicken eggs

133 For cell culture, suspensions of cloacal and tracheal swabs stored in conservation buffer at $-80^{\circ} \mathrm{C}$

134 were thawed, transferred into sterile Eppendorf tubes and centrifuged at 10,000 rpm for $5 \mathrm{~min}$. 135 Supernatant was transferred into a new sterile tube. Antibiotic solution containing $0.1 \mathrm{mg}$ of 136 vancomycine, $0.1 \mathrm{mg}$ of streptomycin, $0.1 \mathrm{mg}$ of kanamycin and $100 \mathrm{U}$ of nystatin was added to the supernatant and the pellet suspensions, which were then incubated at $37^{\circ} \mathrm{C}$ for $2 \mathrm{~h}$ before inoculation.

138 Yolk sacs of 7 day-old embryonated eggs were inoculated with $0.2 \mathrm{ml}$ per egg, and 5 eggs per sample. For each set of inoculation, 3 eggs were inoculated with C. psittaci Loth strain as positive control, and 3 other eggs were kept separately as non-infected controls. Eggs were incubated at $38^{\circ} \mathrm{C}$ and observed daily.

142 Vitellus membranes were collected, then analysed by a MIF test using a direct immunofluorescence assay (Chlamydia direct IF, BioMérieux, Marcy l'Etoile, France).

\subsubsection{Complement fixation test}

146 A microtiter complement fixation test (CFT) for chlamydial antibodies was performed according to the national standard (Collective, 2000). Sera were treated at $59^{\circ} \mathrm{C}$ for 30 min before testing. Guinea pig complement was used at 2 units, and a commercial ornithosis antigen (Dade Behring) was used at the recommended dilution. The presence of $50 \%$ of haemolysis starting from the $1 / 8$ dilution of sera was considered positive.

\subsubsection{MOMP ELISA test}

153 The recombinant major outer membrane protein (rMOMP) ELISA was performed on duck sera being 154 pre-treated with kaolin to remove background activity (Novak et al., 1993). Major outer membrane protein-specific antibody titers were determined using standard protocols and microwell plates coated with rMOMP of the genotype D C. psittaci strain 92/1293 expressing Chlamydiaceae family-specific epitopes. rMOMP was produced in pcDNA1::MOMPHis transfected COS7 cells as described previously (Vanrompay et al., 1998). Briefly, COS7 cells were cultured in Dulbecco modified Eagle medium supplemented with $3.7 \mathrm{~g}$ of sodium bicarbonate/L, $1 \mathrm{mM} \mathrm{L}$-glutamine, and $10 \%$ foetal calf serum (Invitrogen, Merelbeke, Belgium). Transfection with plasmid DNA was performed by the DEAE

161 dextran method. Forty-eight hours post transfection, rMOMP production was monitored by an indirect 
immunofluorescence staining using serovar D and family-specific monoclonal antibodies (Vanrompay et al., 1998) where after the tissue culture flasks were stored at $-70^{\circ}$

${ }^{\circ} \mathrm{C}$. His-tag labelled rMOMP was purified by BD TalonTM (BD Biosciences, Erembodegem, Belgium) affinity chromatography and the protein concentration was determined by the bicinchoninic acid protein assay (Sigma, Bornem,

166 Belgium). MOMP-specific antibody titres were determined using two-fold dilutions of duck sera (starting at a dilution of $1: 100$ ). For the determination of antibody titers, 1:1000 and 1:2000 dilutions of biotinylated rabbit anti-duck IgG $(\mathrm{H}+\mathrm{L})$ antibody (Nordic Immunology) and peroxidase-conjugated streptavidin (Invitrogen) were used, respectively. The results were positive if the absorbance exceeded the cut-off value of the mean of the negative control sera plus three times the standard deviation

\subsection{Genotyping}

174 2.3.1. PCR-RFLP analysis

Alul and Mboll-based PCR-RFLP analysis was performed as previously described (Sayada et al. 1995). Fragments were separated on a $2 \%$ Nusieve agarose gel. Representative chlamydial strains of all known avian serovars were included in the study i.e. VS1 (genotype A), CP3 (genotype B), GR9 (genotype C), NJ1 (genotype D), Cal10 (genotype E) and VS225 (genotype F) C. psittaci reference strains.

\subsubsection{Sequencing}

182 Partial ompA gene fragments were amplified from human samples and animal strains as described previously using ML-genol and ML-genoll primers (Geens et al., 2005). DNA sequencing of these products was done at MWG (Biotech France, Roissy, France).

\subsubsection{Multi-locus VNTR analysis (MLVA)}

187 DNA extracted from human samples and duck isolates were analysed according to a MLVA procedure 188 (Laroucau et al., 2008). Briefly, PCR was performed in a total volume of $15 \mu$ containing 5-10 ng of DNA, 1× PCR reaction buffer, $1 \mathrm{U}$ of Hot start Taq DNA polymerase (Qiagen), $200 \mu \mathrm{M}$ of each

190 deoxynucleotide triphosphate, and $0.3 \mu \mathrm{M}$ of each flanking primer (ChlaPsi_280, ChlaPsi_480,

191 ChlaPsi_605, ChlaPsi_810, ChlaPsi_222, ChlaPsi_281, ChlaPsi_929 or ChlaPsi_1778). The initial 
denaturation step at $95^{\circ} \mathrm{C}$ for 15 min was followed by 40 cycles consisting of denaturation at $95^{\circ} \mathrm{C}$ for

$19330 \mathrm{~s}$, primer annealing at $57^{\circ} \mathrm{C}$ or $60^{\circ} \mathrm{C}$ for $30 \mathrm{~s}$ depending on the primers, and elongation at $72^{\circ} \mathrm{C}$ for

$19445 \mathrm{~s}$. The final extension step was at $72^{\circ} \mathrm{C}$ for $10 \mathrm{~min}$. Five microlitres of amplification product were 195 loaded onto a 4\% Metaphor/standard (50-50) agarose. Gels stained with ethidium bromide were

196 visualized under UV light, and photographed. The size marker used was a 100-bp ladder (Mbi, 197 Euromedex, France).

198

\section{Results}

\subsection{Description of human cases}

201 Between February and March of 2006, four persons working with poultry were admitted to hospital reporting signs of respiratory distress. After avian influenza was ruled out, psittacosis was suspected. A summary of diagnostic data and information on the patients is given in Table 1. Cases 1 and 2 were a married couple working at farm A. The husband had been involved in duck breeding activities for years, and his wife was an occasional assistant worker. While the woman was admitted to resuscitation, the husband was hospitalised for pneumonia. Tracheal aspiration samples collected from the woman proved positive by PCR and culture. Serological analysis of the man's sera revealed an increase of antibody level to chlamydiae. Case 3 was the wife of a duck farm worker (farm B). As she developed respiratory failure, she was transferred to the intensive-care unit for mechanical ventilation. The tracheal aspiration sample was tested positive by PCR. Cases 4 and 5 represent a woman and a man who were working at the intensive breeding farm $\mathrm{C}$. While the fourth case was diagnostically confirmed by PCR, case number 5 , which was not hospitalised, could not be finally confirmed as samples for PCR diagnosis were not available. Nevertheless, the latter can be regarded as a likely case of psittacosis because of the symptoms, the increase in antibody titers and the close

\subsection{Investigation in duck farms associated to cases of psittacosis}

218 All bird flocks present at farms A and B were sampled and examined. While serological testing by CFT

219 was negative for all animals examined, cloacal and/or tracheal chlamydial excretion was detected by

220 PCR in all 6 flocks (Table 1, Figure 1 and data not shown). In each farm, one flock showed a high

221 level of chlamydial excretion (flocks 06-0859 and 06-0889) in both cloacal and conjunctival swabs. 
The other flocks appeared to be less strongly infected, and chlamydiae were only detected in a few ducks, and mainly from cloacal swabs.

224 As farm $\mathrm{C}$ was in an intensive breeding farm, sampling was restricted to the flocks to which the diseased persons were supposed to have had close contact. Chlamydial excretion was detected only in very few animals, and at a low level in 4/5 flocks (Table 1 and Figure 1). Serological testing by CFT was negative for all animals examined (data not shown).

228 Duck sera from these 3 farms were tested by ELISA in order to specifically screen for MOMP antibodies. Positive responses were observed for some samples and the highest titres were obtained

230 for farm C (Table 1 and Figure 2).

231 In the first cell culture trial, PCR-positive samples were inoculated into embryonated chicken eggs. 232 Isolates were successfully cultivated from flocks 06-0859, 06-0871, 06-0886, 06-0889 (farms A and 233 B). In a second trial, PCR-negative samples from flocks $06-0870$ and $06-0885$ were inoculated as 234 PCR-positive samples failed to produce isolates. One isolate was successfully cultured from flock 060885. No strain was isolated from flock $06-870$, as well as from any cultivated sample from farm C

236 (Table 2).

\subsection{Genotyping of isolates}

Isolates from ducks were first analysed by PCR-RFLP using primers CTU/CTL. Based on restriction patterns generated by enzymes Alul and Mboll, isolates 06-0859, 06-0871, 06-0885, 06-0886, 060889 showed similar patterns. The Alul RFLP profile was identical to a genotype B profile (CP3),

242 whereas their Mboll RFLP profile was identical to those of a genotype A strain (VS1) (Figure 3 and 243 data not shown).

244 In order to verify the genotyping results, ompA sequencing was performed on samples collected from 245 the confirmed human cases 1, 3 and 5 (one from each farm), as well as on all the duck isolates 246 obtained. All sequences were identical, but not completely homologous to the C. psittaci sequences deposited in public databases. The sequence of the isolate obtained from flock 06-859 has been 248 deposited under GenBank acc.no. EU159263.

249 Furthermore, human samples and duck strains were analysed by MLVA using primers ChlaPsi_280, 250 ChlaPsi_480, ChlaPsi_605, ChlaPsi_810, ChlaPsi_222, ChlaPsi_281, ChlaPsi_929 and 251 ChlaPsi_1778. With these 8 primers, similar patterns (i.e. 1:3:2:-:6:3:-:4) were obtained for all duck 

human sample of case 4 from farm C (Figure 4 and data not shown).

254

\section{Discussion} in all three duck farms concerned. to assess the contamination level of the premises.

strains and human samples from farms $A$ and $B$, whereas a 2:3:2:-:6:3:-:4 pattern was obtained for the

The present investigation conducted around severe human cases of respiratory distress led to the confirmation of psittacosis by PCR in three cases and the demonstration of the presence of C. psittaci

In the past, significant morbidity and mortality rates were found in infected duck flocks, which apparently depended on age and the presence of concurrent infection with salmonellae. Henceforth, disease signs in outbreaks which occurred in European duck farms in recent decades appeared to be minimal or entirely absent (Andersen et al., 1997), as observed in our study. However, in this case, chlamydial excretion was clearly observed in many of the ducks. The use of real-time PCR allowed evaluating the level of excretion and, consequently, the level of exposure for the personnel. In two of the farms ( $A$ and $B$ ), a single flock was identified as strongly excreting, whereas in the third farm, the level of excretion was much lower and confined to only few animals. Considering this third farm, the link between bacterial load and human infection was less evident, but artificial insemination activities performed on that farm imply close contact between animals and humans. In this farm, the first clinical signs in the fifth patient appeared at the end of the December, whereas the earliest symptoms from the other patient emerged about 60 days later. As for the 2 other farms, no clinical signs were observed with the animals of farm C. It can be hypothesised that these animals were continuous lowlevel shedders, which would mean a regular exposition of the workers. In future studies, it would be interesting to test environmental samples such as air, ventilation system, air filters, cages etc. in order

The apparent variation in pathogenicity of $C$. psittaci strains has been attributed to either a change in virulence or improved control of other synergistic pathogens (Andersen et al., 1997). Another possible explanation could be the presence in the flocks of different chlamydial genotypes that induce different pathology in ducks. Within the species of $C$. psittaci, avian strains can be differentiated by serological (Andersen, 1991, 1997) or molecular tools (Sayada et al., 1995) and classified into serotypes or genotypes, respectively. Until now, very few isolates from European outbreaks related to ducks have been serotyped, all of them being serotype $\mathrm{C}$, one of them occurring in a mixed infection with serovar 
B (Vanrompay and Andersen, 1993). In the present study, molecular genotyping performed on human samples and animal isolates led to inconclusive results from PCR-RFLP, since the pattern observed was an intermediate between genotypes $\mathrm{A}(\mathrm{Alul})$ and $\mathrm{B}$ (Mboll). Sequences of the ompA gene from duck and human samples were identical (GenBank acc.no. EU159263), but at the same time unique in that they were not completely homologous to any other sequence deposited in GenBank. Multiple sequence alignment and DNA microarray analysis revealed that the respective strain belongs to genotype E/B, where it represents a hitherto unknown subtype designated EB-859 (Sachse et al., 2008). When the MLVA, which is based on the detection of tandem repeats dispersed throughout the genome, was applied to these samples (from humans and ducks), it led to identification of two distinct patterns which were also found in other duck isolates showing different PCR-RFLP patterns $(E, C$ or inconclusive) (Laroucau et al., 2008). These two patterns were also observed in a study conducted on chlamydia-positive specimens from ducks sampled in a major breeding area (Laroucau, unpublished data). This means that, despite the identity of ompA sequences, different $C$. psittaci isolates occurred in these duck flocks. It seems that only more sophisticated tests of high discriminatory capacity and more detailed screening could reveal the entire genetic diversity of $C$. psittaci strains present. The confirmed human cases reported here concerned either persons having had occasional contact 298 with ducks or individuals working at artificial insemination. Regarding other studies carried out in France, it appears that chlamydial infections in duck breeding are very widespread (Léon et al., 2004; Guérin et al., 2006). Nevertheless, these serious human cases seem to be exceptional and could be explained by the late stage of ongoing antibiotic treatment of the patients, as avian flu was initially suspected. Nevertheless, owing to the fact that psittacosis is not a notifiable disease in France, it is also probable that other cases have remained undiagnosed. The present human cases were notified to the National Institute for Public Health Surveillance (InVS) when avian flu alert was activated, and cases of pneumonia in relation with poultry had to be declared.

306 It is not surprising, as was previously observed (Arzey et al., 1990), that all duck sera were negative 307 by CFT serology, although intense excretion was clearly demonstrated in this study. The lack of 308 sensitivity of CFT prompted us to use a C. psittaci MOMP ELISA (Verminnen et al., 2006). Samples generating the highest positive responses were those from farm $\mathrm{C}$, in which less/no excretor animals were detected. The most important serological responses were observed in the oldest flocks (25 week-old versus 4-14 week-old), which were also of a different breed (Pekin instead of mallard). In this 
312 context, breed, age, breeding techniques could have an impact on the chlamydial infection. It is

313 possible that in farm $\mathrm{C}$, animals were old enough to control the infection. No information is available to

314 find out whether farm $\mathrm{C}$ had gone through a similar excretion patter as farms $\mathrm{A}$ and $\mathrm{B}$ beforehand. In

315 farm C, culture was negative, but chlamydial DNA and high antibody titers were still detectable in 25

316 week-old ducks. It is possible that the other two farms ( $A$ and $B$ ) were dealing with a more recent, acute infection. Except for flock 06-0886, all flocks had at least one lgG positive sample, but in most

318 of the positive flocks (except 06-0859) only a few animals showed lgG titres. It is known that the onset of antibody production in the host is deferred after primary contact with the pathogen. In turkeys, depending on the infective dose and the strain, the cloaca becomes positive at 5 to 8 days post infection (Vanrompay et al., 1995) and IgM antibodies appear at 7 days post infection, IgG antibodies appear later on between 10 and 14 days post infection, reaching their highest level at 3 weeks post infection (Van Loock et al., 2006). The conjugate should detect IgG and IgM in theory, because it detects the heavy and light chains. Thus, either no antibodies at all or predominantly IgM were present in flocks of farm A (except 06-0859) and B, and, therefore, the ELISA was negative for most animals even though chlamydial DNA could be detected and in some cases isolates could be grown. These discrepancies require further studies.

328 The data of the present study confirm that epidemiological investigation of psittacosis in ducks cannot be done using serology alone as no correlation between antibody presence and excretion was observed, but direct DNA-based or antigen-based detection of the chlamydiae and/or isolation are 331 highly desirable.

332 In conclusion, the findings of the present study demonstrate that chlamydial infection of duck flocks is a public health concern. It can be recommended that efficient measures be taken to ensure a high

334 health status of duck flocks, and chlamydia monitoring be conducted on a more regular basis. This work is an example of cooperation between veterinary and human medicine being fully

336 complementary and, at the same time, indispensable to improve our knowledge on avian chlamydiosis. 


\section{Conflict of interest statement}

341 None of the authors ( $K L, B d B, F V, M C, C B, T H, K V, F O, I C, C B, B D, G Z, D V, B G B, K S)$ has a

342 financial or personal relationship with other people or organisations that could inappropriately

343 influence or bias this paper.

Acknowledgements

346 We are grateful to R. Goffette, R. Delavergne, F. Pouilly, A. Thébault from French veterinary services

347 and to C. Larsen of the National Institute for Public Health Surveillance (InVS) for their precious help.

348 We are also grateful to D. Toquin (AFSSA Ploufragan) for providing EOPS duck sera.

349 The study is an integral part of the European COST Action 855, "Animal chlamydioses and the 350 zoonotic implications".

\section{References}

Andersen, A.A. 1991. Serotyping of Chlamydia psittaci isolates using serovar-specific monoclonal antibodies with the microimmunofluorescence test. J. Clin. Microbiol. 29: 707-711.

Andersen, A.A. 1997. Two new serovars of Chlamydia psittaci from North American birds. J. Vet. Diag. Invest. 9: 159-164.

Andersen, A.A., Grimesn, J.E., Wyrick, P.B. 1997. Chlamydiosis (psittacosis, ornithosis) in diseases of poultry, $10^{\text {th }}$ edition, lowa state university press, Ames, lowa, USA. p 333-349.

361 Andersen, A.A., Vanrompay, D. 2000. Avian chlamydiosis. Rev. Sci. Tech. 19: 396-404.

362 Arzey, K.E., Arzey, G.G., Reece, R.L. 1990. Chlamydiosis in commercial ducks. Aust. Vet. J. 67(9): 333-334.

Vanrompay, D., Andersen, A.A., Ducatelle, R., Haesebrouck, F. 1993. Serotyping of European isolates of Chlamydia psittaci from poultry and other birds. J. Clin. Microbiol. 31: 134-137. outbreak. Vet. Rec. 116(8): 223. 
Collective, 2000. Méthodes d'analyse en santé animale : recherche d'anticorps contre la chlamydiose chez les oiseaux par la technique de fixation du complément. Norme Française AFNOR NF U47-007.

De Martino, S.J., de Barbeyrac, B., Piémont, Y., Barthel, C., Monteil, H., Jaulhac, B. 2006. Detection of Chlamydia trachomatis DNA using MagNA Pure DNA extraction and Cobas Amplicor CT/NG amplification. Clin. Microbiol. Infect.12: 576-579.

Ehricht, R., Slickers, P., Goellner, S., Hotzel, H., Sachse, K. 2006. Optimized DNA microarray assay allows detection and genotyping of single PCR-amplifiable target copies. Mol. Cell. Probes 20:60-63

Gaede, W., Reckling, K.F., Dresenkamp, B., Kenklies, S., Schubert, E., Noack, U., Irmscher, H.M., Ludwig, C., Hotzel, H., Sachse, K. 2008. Chlamydophila psittaci infections in humans during an outbreak of psittacosis from poultry in Germany. Zoonoses \& Public Health. 55(4):184-188.

Geens, T., Desplanques, A., Van Loock, M., Bonner, B.M., Kaleta, E.F., Magnino, S., Andersen, A.A., Everett, K.D., Vanrompay, D. 2005. Sequencing of the Chlamydophila psittaci ompA gene reveals a new genotype, E/B, and the need for a rapid discriminatory genotyping method. J. Clin. Microbiol. 43(5): 2456-2461.

Guérin, J.L., Ballot, A., Sraka, B., Léon, O. 2006. Portage de Chlamydophila psittaci dans la filière canard mulard : évaluation du portage chez les reproducteurs et incidence sur le statut du caneton. Proceedings des $7^{\text {èmes }}$ Journées de la recherche sur les palmipèdes à foie gras, 1819 octobre 2006, Arcachon, France. p 37-40.

Heddema, E.R., van Hannen, E.J., Duim, B., Vandenbroucke-Grauls, C.M., Pannekoek, Y. 2006. Genotyping of Chlamydophila psittaci in human samples. Emerg. Infect. Dis. 12(12): 19891990.

Hinton, D.G., Shipley, A., Galvin, J.W., Harkin, J.T., Brunton, R.A. 1993. Chlamydiosis in workers at a duck farm and processing plant. Aust. Vet. J. 70(5): 174-176.

Huminer, D., Pitlik, S., Kitayin, D., Weissman, Y., Samra, Z. 1992. Prevalence of Chlamydia psittaci infection among persons who work with birds. Isr. J. Med. Sci. 28(10): 739-741.

Huminer, D., Samra, Z., Weisman, Y., Pitlik, S. 1988. Family outbreaks of psittacosis in Israel. Lancet. 2(8611): 615-618. 
Kaleta, E.F., Taday, E.M. 2003. Avian host range of Chlamydophila spp. based on isolation, antigen detection and serology. Avian Pathol. 32(5): 435-461.

Laroucau, K., Thierry, S., Vorimore, F., Blanco, K., Kaleta, E., Hoop, R., Magnino, S., Vanrompay, D., Sachse, K., Myers, G., Bavoil, P., Vergnaud, G., Pourcel, C. 2008. High resolution typing of Chlamydophila psittaci by Multilocus VNTR Analysis (MLVA). Infect Genet Evol. 8(2): 171-181.

Léon, O., Sraka, B., Ballot, A., Armand, C., Guérin, J.L. 2004. Evaluation du portage de Chlamydophila psittaci au sein de la filière canards gras : implications pour la santé publique. Proceedings des $6^{\text {èmes }}$ Journées de la recherche sur les palmipèdes à foie gras, 7-8 octobre 2004, Arcachon, France.

Loock, M.V., Loots, K., Zande, S.V., Heerden, M.V., Nauwynck, H., Goddeeris, B.M., Vanrompay, D. 2006. Pathogenic interactions between Chlamydophila psittaci and avian pneumovirus infections in turkeys. Vet Microbiol. 112(1):53-63.

Ménard, A., Clerc, M., Subtil, A., Megraud, F., Bebear, C., de Barbeyrac, B. 2006. Development of a real-time PCR for the detection of Chlamydia psittaci. J. Med. Microbiol. 55: 471-473.

Novak, M., Moldoveanu, Z., Schafer, D.P., Mestecky, J., Compans, R.W. 1993. Murine model for evaluation of protective immunity to influenza virus. Vaccine 11: 55-60.

Sachse, K., Laroucau, K., Hotzel, H., Schubert, E., Ehricht, R., Slickers, P. 2008. Genotyping of Chlamydophila psittaci using a new DNA microarray assay based on sequence analysis of ompA genes. BMC Microbiology 8, 63 (17Apr2008).

Saito, T., Ohnishi, J., Mori, Y., linuma, Y., Ichiyama, S., Kohi, F. 2005. Infection by Chlamydophilia avium in an elderly couple working in a pet shop. J. Clin. Microbiol. 43(6): 3011-3013.

Sayada, C., Andersen, A.A., Storey, C., Milon, A., Eb, F., Hashimoto, N., Hirai, K., Elion, J., Denamur, E. 1995. Usefulness of omp1 restriction mapping for avian Chlamydia psittaci isolate differentiation. Res. Microbiol. 146(2): 155-165.

Spencer, W., Johnson, F. 1983. Simple transport medium for the isolation of Chlamydia psittaci from clinical material. Vet. Rec. 113: 535-536.

Sudler, C., Hoelzle, L.E., Schiller, I., Hoop, R.K. 2004. Molecular characterisation of chlamydial isolates from birds. Vet. Microbiol. 98(3-4): 235-241. 
425 Vanrompay, D., Mast, J., Ducatelle, R., Haesebrouck, F., Goddeeris, B. 1995. Chlamydia psittaci in turkeys: pathogenesis of infections in avian serovars A, B and D. Vet Microbiol. 47(3-4):245256

428 Vanrompay, D., Cox, E., Mast, J., Goddeeris, B., Volckaert, G. 1998. High level expression of Chlamydia psittaci major outer membrane protein in COS cells and in skeletal muscles of turkeys. Infect. Immun. 66: 5494-5500.

431 Verminnen, K., Van Loock, M., Hafez, H.M., Ducatelle, R., Haesebrouck, F., Vanrompay, D. 2006. Evaluation of a recombinant enzyme-linked immunosorbent assay for detecting Chlamydophila psittaci antibodies in turkey sera. Vet Res. 37(4):623-632. 


\section{Figure 1}

Monitoring of cloacal $(\mathrm{C})$ and tracheal $(\mathrm{T})$ chlamydial excretion in ducks from all flocks under investigation using quantitative real-time PCR: average $\mathrm{Ct}$ values and standard deviations for each studied flocks.

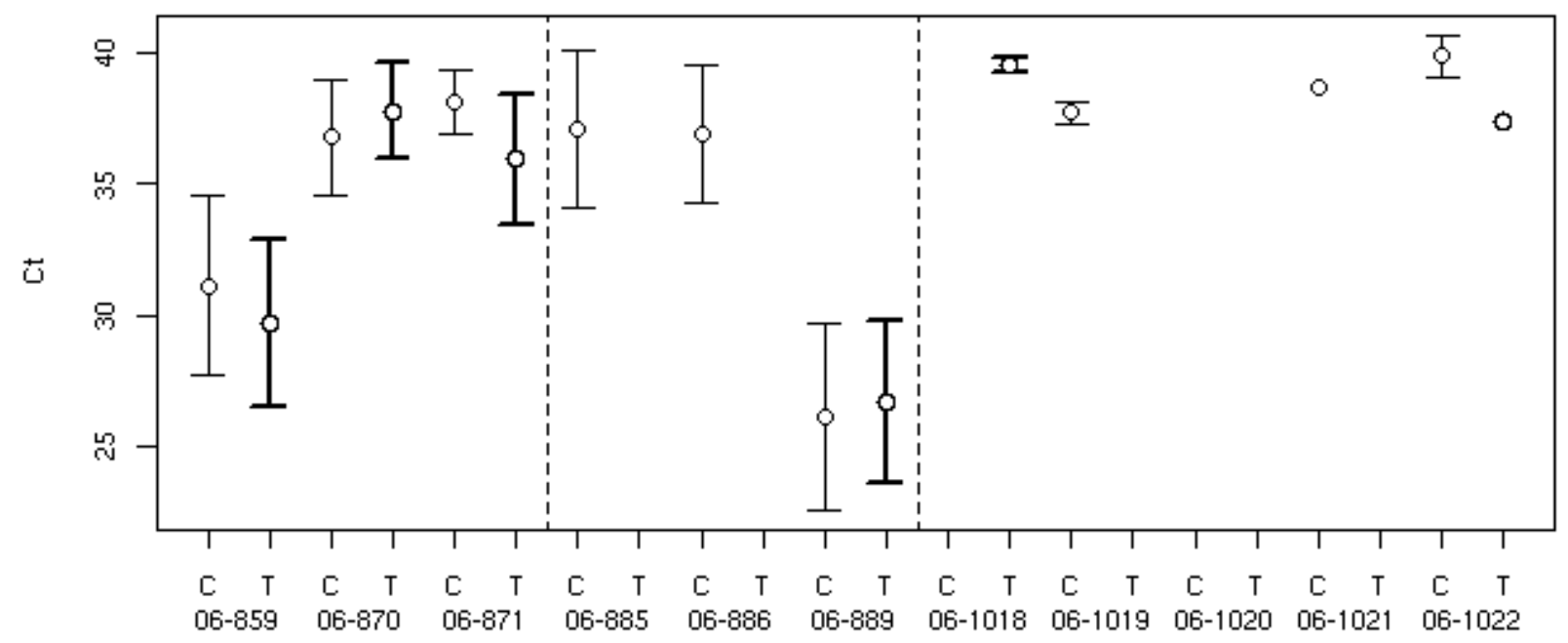




\section{Figure 2}

Monitoring of MOMP antibodies in duck sera from all flocks using ELISA: average titre $(\log 10)$ and standard deviations for each studied flock. The titre corresponds to the final serum dilution being positive.

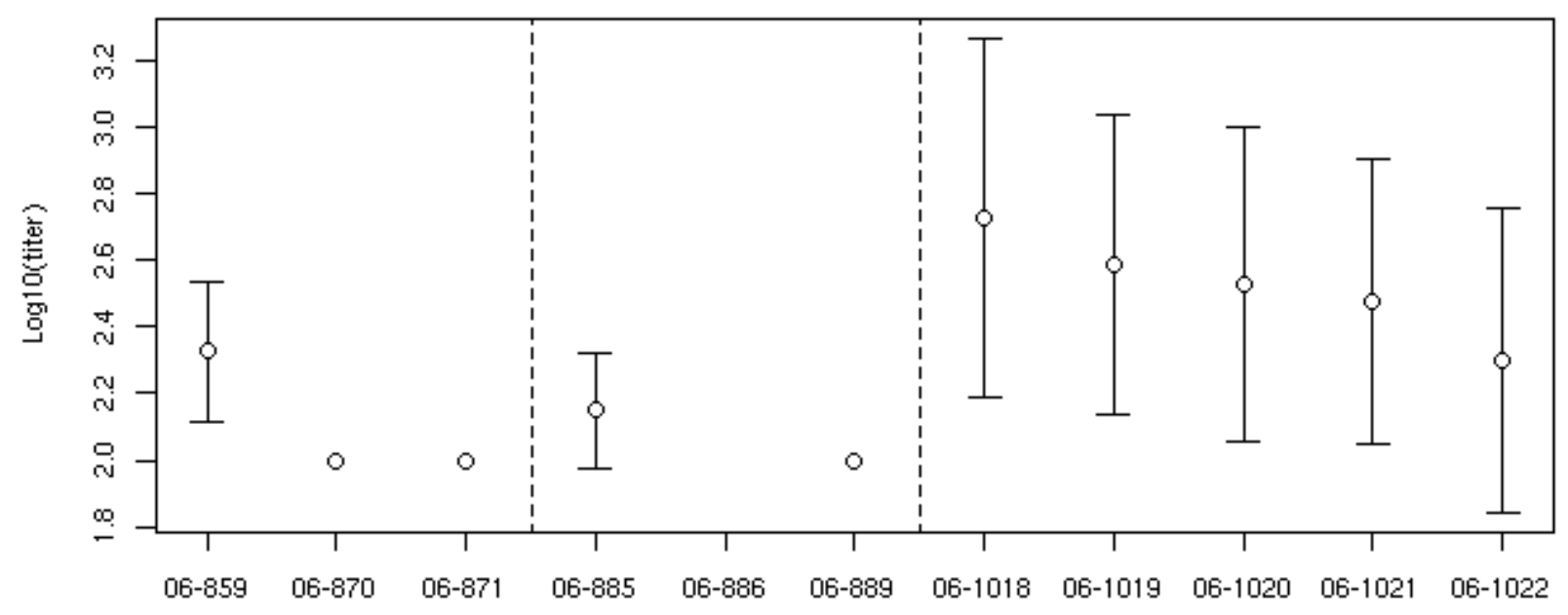




\section{Figure 3}

Enzyme restriction profiles of CTU/CTL PCR products for 6 representative avian isolates (VS1, CP3, GR9, NJ1, Cal10 and VS225) (Lanes 1 to 6) and for 2 duck isolates 06-0859 (flock A) and 06-0889 (flock B) (Lanes 7, 8). A 100-bp ladder (Mbi, Euromedex, France) is run on the side of each group of samples.
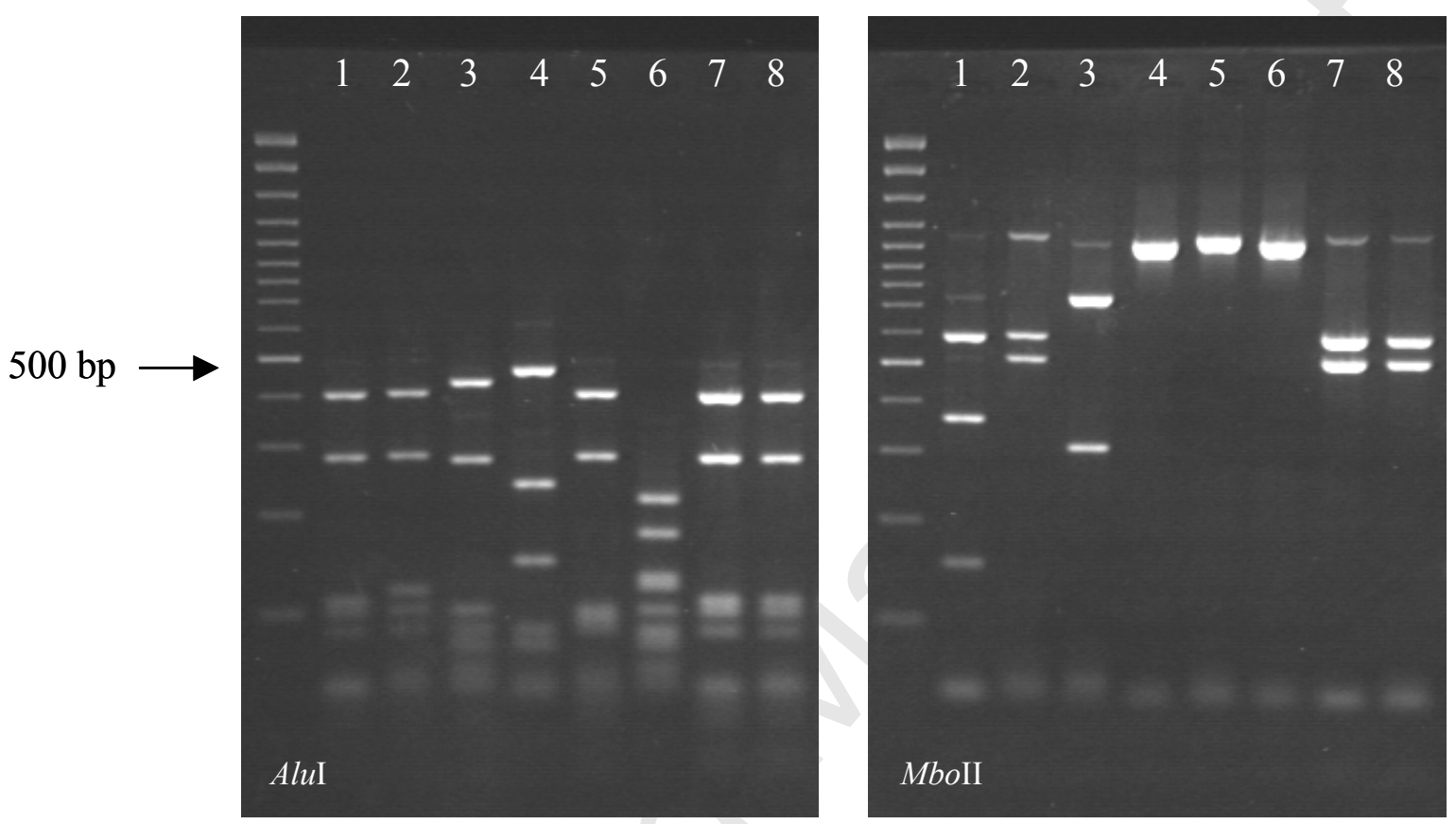


\section{Figure 4}

PCR amplification of 8 VNTRs (ChlaPsi_280, ChlaPsi_480, ChlaPsi_605, ChlaPSi_810, ChlaPsi_222, ChlaPsi_281, ChlaPsi_929, ChlaPsi_1778) on human samples confirmed positive by PCR (A: case $n^{\circ} 2$; B: case $n^{\circ} 3$ and C: case $n^{\circ} 4$ ) (seeTable 1 ).

A 100 -bp ladder (100 to $1,000 \mathrm{bp}$ ) is run on both sides of each group of samples. The number of repeat units within each allele is indicated.

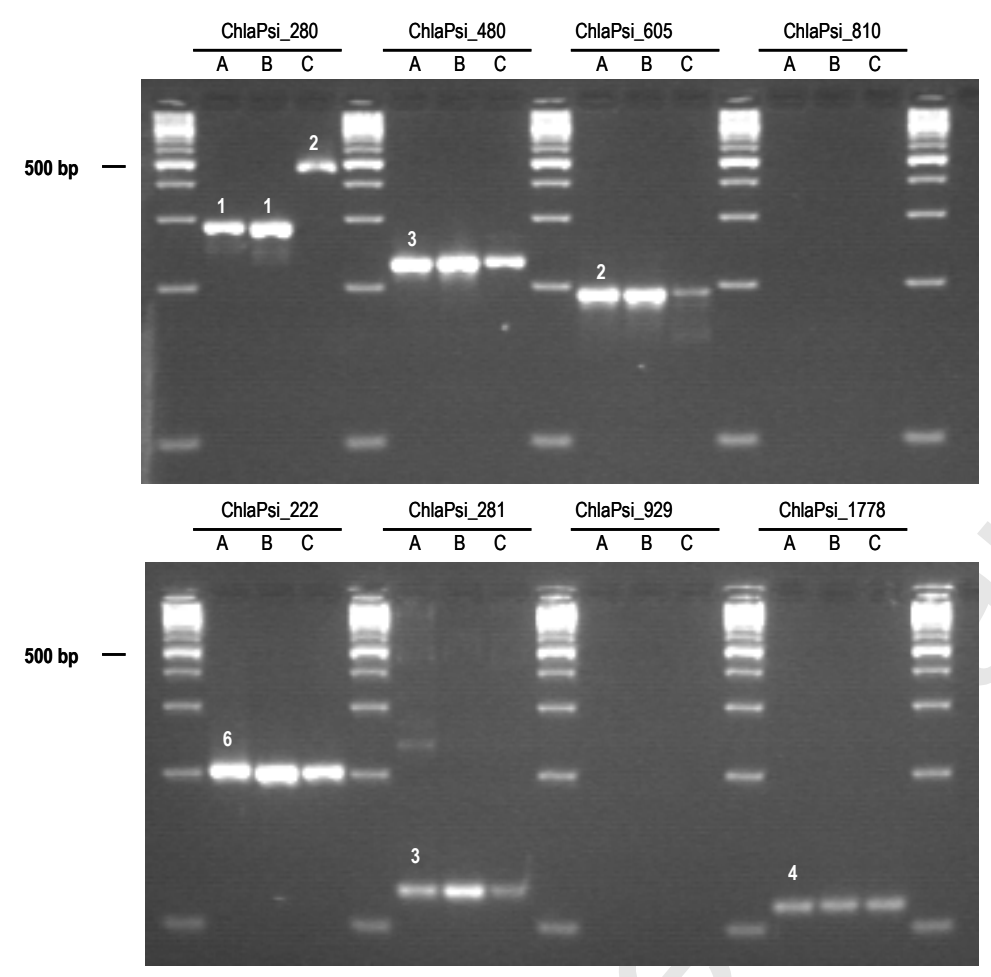




\section{Table 1}

Human cases: clinical signs and and diagnostic data

\begin{tabular}{|c|c|c|c|c|c|c|c|c|c|c|c|}
\hline & $\mathrm{N}^{\circ}$ case & Sex & $\begin{array}{c}\text { Age } \\
\text { (years) }\end{array}$ & $\begin{array}{c}\text { First clinical } \\
\text { signs }\end{array}$ & Hospitalisation & $\begin{array}{l}\text { Clinical } \\
\text { diagnosis }\end{array}$ & date & $\begin{array}{l}\text { ogy } \\
\text { results }\end{array}$ & $\begin{array}{l}\text { Respiratory } \\
\text { samples }\end{array}$ & PCR & Culture \\
\hline \multirow{3}{*}{ Plant A } & \multirow{2}{*}{1} & \multirow{2}{*}{ M } & \multirow{2}{*}{43} & \multirow{2}{*}{$19 / 02 / 2006$} & \multirow{2}{*}{$27 / 02 / 2006$} & \multirow{2}{*}{ Pneumonia - } & $01 / 03 / 2006$ & $\begin{array}{c}\lg \mathrm{C}<1 / 16 \\
\text { IgM positive }\end{array}$ & \multirow{2}{*}{$\begin{array}{l}\text { Throat swab } \\
\text { sample }\end{array}$} & \multirow{2}{*}{ negative } & \multirow{2}{*}{ negative } \\
\hline & & & & & & & $03 / 03 / 2006$ & $\begin{array}{l}\lg \text { 1/128 } \\
\text { IgM positive }\end{array}$ & & & \\
\hline & 2 & $\mathrm{~F}$ & 46 & $20 / 02 / 2006$ & $26 / 02 / 2006$ & $\begin{array}{l}\text { Pneumonia } \\
+ \text { ARDS }\end{array}$ & $27 / 02 / 2006$ & $\begin{array}{l}\text { IgG 1/256 } \\
\text { IgM positive }\end{array}$ & $\begin{array}{l}\text { Tracheal } \\
\text { aspiration }\end{array}$ & positive & positive \\
\hline Plant B & 3 & $\mathrm{~F}$ & 51 & $20 / 02 / 2006$ & $27 / 02 / 2006$ & $\begin{array}{l}\text { Pneumonia } \\
+ \text { ARDS }\end{array}$ & $03 / 03 / 2006$ & $\begin{array}{c}\lg \mathrm{1} 1 / 16 \\
\text { IgM negative }\end{array}$ & BAL & positive & negative \\
\hline \multirow{4}{*}{ Plant C } & 4 & $\mathrm{~F}$ & 44 & $01 / 03 / 2006$ & 04/03/2006 & $\begin{array}{l}\text { Pneumonia } \\
\text { + ARDS }\end{array}$ & $06 / 03 / 2006$ & $\begin{array}{c}\lg G<1 / 16 \\
\lg M \text { negative }\end{array}$ & $\begin{array}{l}\text { Tracheal } \\
\text { aspiration }\end{array}$ & positive & negative \\
\hline & \multirow{3}{*}{5} & \multirow{3}{*}{ M } & \multirow{3}{*}{38} & \multirow{3}{*}{$26 / 12 / 2005$} & \multirow{3}{*}{ - } & & $05 / 01 / 2006$ & $\operatorname{lgG} 1 / 64$ & \multirow{3}{*}{ ND } & \multirow{3}{*}{ ND } & \multirow{3}{*}{ ND } \\
\hline & & & & & & Pneumonia & \multirow{2}{*}{$23 / 02 / 2006$} & $\lg 1_{1 / 128}$ & & & \\
\hline & & & & & & & & IgM negative & & & \\
\hline
\end{tabular}

ARDS: acute respiratory distress syndrome; BAL: broncho-alveolar fluid; ND: not done. 
Table 2

Characteristics of investigated duck flocks

\begin{tabular}{|c|c|c|c|c|c|c|c|c|c|c|c|c|}
\hline \multirow[b]{2}{*}{$\begin{array}{c}\text { Flock } \\
\text { identification }\end{array}$} & \multirow[b]{2}{*}{ Race } & \multirow[b]{2}{*}{$\begin{array}{c}\text { Age } \\
\text { (week-old) }\end{array}$} & \multirow[b]{2}{*}{ Effective } & \multirow[b]{2}{*}{ Production } & \multicolumn{4}{|c|}{ PCR positive samples } & \multicolumn{2}{|c|}{ culture positive samples } & \multicolumn{2}{|c|}{ ELISA } \\
\hline & & & & & trachea & $\begin{array}{c}\text { mean of Ct } \\
\text { value } \\
\text { (trachea) }\end{array}$ & cloacae & $\begin{array}{c}\text { mean of Ct } \\
\text { value } \\
\text { (cloacae) }\end{array}$ & trachea & cloacae & $\begin{array}{c}\text { positive } \\
\text { samples }\end{array}$ & $\begin{array}{c}\text { mean of the } \\
\text { final serum } \\
\text { dilution being } \\
\text { positive }\end{array}$ \\
\hline Plant A & & & & & & 33,0 & & 34,0 & & & & \\
\hline 06-0859 & mallard & 4 & 4000 & fattening & $19 / 20$ & 29,7 & $20 / 20$ & 31,1 & $3 / 3$ & nd & $11 / 20$ & 236 \\
\hline $06-0870$ & mallard & 8 & 4500 & fattening & $6 / 20$ & 37,8 & $9 / 20$ & 36,8 & $0 / 6$ & $0 / 9$ & $2 / 20$ & 100 \\
\hline 06-0871 & mallard & 11 & 4700 & fattening & $12 / 20$ & 36,0 & $8 / 20$ & 38,2 & $4 / 4$ & nd & $2 / 19$ & 100 \\
\hline Plant B & & & & & & 26,7 & & 30,8 & & $\theta$ & & \\
\hline 06-0885 & mallard & 13 & 400 & fattening & $0 / 20$ & na & $4 / 20$ & 37,1 & $0 / 9$ & $1 / 17$ & $4 / 20$ & 150 \\
\hline 06-0886 & mallard & 14 & 1300 & fattening & $0 / 20$ & na & $11 / 20$ & 36,9 & nd & $2 / 4$ & $0 / 19$ & 0 \\
\hline 06-0889 & mallard & 5 & 1500 & fattening & $20 / 20$ & 26,7 & $20 / 20$ & 26,1 & $3 / 3$ & nd & $1 / 20$ & 100 \\
\hline Plant C & & & & & & 38,8 & & 38,8 & & & & \\
\hline 06-1018 & pekin & 25 & 1400 & reproduction & $2 / 20$ & 39,6 & $0 / 20$ & na & $0 / 2$ & $0 / 1$ & $19 / 20$ & 1015 \\
\hline 06-1019 & pekin & 25 & 1500 & reproduction & $0 / 20$ & na & $3 / 20$ & 37,7 & $0 / 3$ & $0 / 19$ & $20 / 20$ & 660 \\
\hline 06-1020 & pekin & 25 & 900 & reproduction & $0 / 20$ & na & $0 / 20$ & na & nd & nd & $16 / 20$ & 625 \\
\hline 06-1021 & pekin & 25 & - & reproduction & $0 / 20$ & na & $1 / 20$ & 38,7 & nd & $0 / 1$ & $17 / 20$ & 529 \\
\hline 06-1022 & mallard & - & 6000 & fattening & $1 / 20$ & 37,4 & $3 / 20$ & 39,9 & $0 / 1$ & $0 / 3$ & $7 / 20$ & 371 \\
\hline
\end{tabular}

